\title{
Diabetes Mellitus, Hba1c and Risk of Hospitalization for Pneumonia
}

\author{
Senay Ozturk Durmaz ${ }^{1 *}$, Ece Celik ${ }^{2}$ and Mehmet Celik ${ }^{3}$ \\ ${ }^{1}$ Department of Infectious Diseases and Clinical Microbiology, Antalya Kepez State Hospital, Turkey \\ ${ }^{2}$ Division of Allergy and Clinical Immunology, Antalya University Medical Faculty, Turkey \\ ${ }^{3}$ Department of Endocrinology and Metabolism, Antalya Kepez State Hospital, Turkey
}

Submission: March 18, 2019; Published: April 10, 2019

*Corresponding author: Senay Ozturk Durmaz, Department of Infectious Diseases and Clinical Microbiology, Antalya Kepez State Hospital, Antalya, Turkey

Abstract

Objective: To evaluate the hospitalization rates for pneumonia in patients with diabetes mellitus and to evaluate the effect of HbA1c on hospitalization for pneumonia.

Materials and Methods: We defined patients hospitalized with pneumonia between January 2018 and January 2019, and the health services databases were retrospectively reviewed. Relative risk and risk factors for pneumonia in diabetic and non-diabetic patients were evaluated.

Results: The files of 597 patients hospitalized for pneumonia were evaluated retrospectively. The mean age of the patients was $66.8 \pm 15$ years. $353(59.1 \%)$ of the patients were males and 244 (40.9\%) were females. Diabetes mellitus (DM) was present in 80 (13.4\%) patients and 517 (86.6\%) patients did not have DM. Mortality was seen in 5 patients (6.3\%) with DM and 27 patients (5.2\%) without DM. There was no statistically significant difference between two groups in terms of mortality $(\mathrm{p}=0.70)$. Six $(7.5 \%)$ patients with DM and $66(12.8 \%)$ non-diabetic patients were hospitalized in intensive care unit. There was no statistically significant difference between two groups in terms of admission to intensive care unit $(p=0.17)$. Patients with COPD were excluded from the study after statistical analysis; intensive care unit stay was significantly lower in diabetic patients (p: 0.010). No statistically significant difference was found between two groups in terms of pneumonia-associated mortality ( $p$ : 0.478).

Conclusion: In diabetic patients, HbA1c values higher than target level and poor long-term glycemic control clearly increase the risk of hospitalization with pneumonia

Keywords: Pneumonia; Diabetes Mellitus; HbA1c

\section{Introduction}

Diabetes mellitus (DM) is one of the most common chronic diseases in the world. It constitutes a huge economic burden on countries' health resources [1]. Studies have shown that community-acquired pneumonia is more common in diabetic patients and response to treatment is poor among these subjects. Although some studies suggest increased pneumonia related mortality for diabetics, others confirm no association [2-5]. The aim of this study was to evaluate the incidence of acquired pneumonia in diabetic population and to evaluate the effect of HbA1c on hospitalization due to pneumonia.

\section{Materials and Methods}

Between January 2018 and January 2019, we identified patients hospitalized with pneumonia, and health services databases were retrospectively reviewed. Relative risk and risk factors for pneumonia in diabetic and non-diabetic patients were evaluated. Data were analyzed using a commercially available software package (SPSS for Windows, version 22.0; SPSS Inc; NY,). In univariate analyses, differences in proportions were tested with the X2 test or Fisher exact test, and differences in the means of dimensional variables were tested with the Student $t$ test. The level of significance was set at $\mathrm{p}<0.05$.

\section{Results}

In this study, the files of 597 patients who were hospitalized in Antalya Kepez State Hospital between January 2018 and January 2019 were evaluated retrospectively. The mean age of the patients was $66.8 \pm 15$ years. While 353 (59.1\%) of the patients were males, 244 (40.9\%) were females. While chronic obstructive pulmonary disease (COPD) was present in 321 (53.8\%) of the patients, $276(46.2 \%)$ had no COPD. Diabetes mellitus was present in $80(13.4 \%)$ patients and 517 (86.6\%) patients did not have DM. The number of patients with HbA1c $\leq 7 \%$ was 17 (21.25\%), HbA1c was > $7-\% 10$ in 50 subjects 
(62.5\%) and HbA1c was> 10 in 13 patients (16.25\%) (Table 1). While $72(12.1 \%)$ of the patients were followed up in intensive care unit, 525 (87.9\%) patients were hospitalized in the ward.

Table 1: Relationship between $\mathrm{HbA1c}$ and pneumonia in diabetic patients.

\begin{tabular}{|c|c|c|c|c|c|}
\hline & \multicolumn{3}{|c|}{ HbA1c (\%) } \\
\hline & & & $\leq 7$ & $>7-\leq 10$ & $>10$ \\
\hline \multirow{2}{*}{\multicolumn{2}{|c|}{ Pneumonia }} & $\mathrm{n}$ & 17 & 50 & 13 \\
\hline & & $\%$ & 21.25 & 62.5 & 16.25 \\
\hline \multirow{2}{*}{\multicolumn{2}{|c|}{ Mortality }} & $\mathrm{n}$ & 0 & 4 & 1 \\
\hline & & $\%$ & 0 & 8 & 7.7 \\
\hline \multirow{2}{*}{\multicolumn{2}{|c|}{$\begin{array}{l}\text { Patients followed in intensive } \\
\text { care unit }\end{array}$}} & $\mathrm{n}$ & 1 & 5 & 0 \\
\hline & & $\%$ & 5.9 & 10 & 0 \\
\hline \multirow{8}{*}{ Age } & \multirow{2}{*}{$18-39$} & $\mathrm{n}$ & 0 & 0 & 1 \\
\hline & & $\%$ & 0 & 0 & 7.7 \\
\hline & \multirow{2}{*}{$40-64$} & $\mathrm{n}$ & 7 & 21 & 7 \\
\hline & & $\%$ & 41.2 & 42 & 53.8 \\
\hline & \multirow{2}{*}{$65-79$} & $\mathrm{n}$ & 7 & 24 & 5 \\
\hline & & $\%$ & 41.2 & 48 & 38.5 \\
\hline & \multirow{2}{*}{$>80$} & $\mathrm{n}$ & 3 & 5 & 0 \\
\hline & & $\%$ & 17.6 & 10 & 0 \\
\hline
\end{tabular}

While 32 (5.4\%) of the patients had mortality, 565 (94.6\%) patients were discharged. Mortality was seen 5 patients $(6.3 \%)$ with DM and 27 patients (5.2\%) without DM, there was no statistically significant difference between two groups $(\mathrm{p}=0.70)$. Six $(7.5 \%)$ patients with DM and 66 (12.8\%) non-diabetic patients were hospitalized in intensive care unit. There was no statistically significant difference between two groups in terms of admission to intensive care unit $(\mathrm{p}=0.17)$. After excluding patients with COPD, patients with pneumonia were evaluated as two groups according to the presence of diabetes mellitus; intensive care unit hospitalization was significantly lower in diabetic patients (p: 0.010). There was no statistically significant difference between two groups in terms of pneumonia associated mortality (p: 0.478) (Table 2).

Table 2: Pneumonia among diabetics and non-diabetics.

\begin{tabular}{|c|c|c|c|}
\hline & $\begin{array}{c}\text { Diabetes Mellitus } \\
(+) \mathbf{n : 8 0}\end{array}$ & $\begin{array}{c}\text { Diabetes Mellitus } \\
(-\mathbf{-}) \mathbf{n}: \mathbf{2 4 0}\end{array}$ & $\mathbf{P}$ \\
\hline Age (mean+SD) & $65.9 \pm 10.7$ & $67.7 \pm 18$ & 0.013 \\
\hline $\begin{array}{c}\text { Gender } \\
\text { (Female/Male) }\end{array}$ & $43 / 37$ & $105 / 135$ & 0.12 \\
\hline $\begin{array}{c}\text { Pneumonia } \\
\text { (n, \%) }\end{array}$ & $80(13.4 \%)$ & $240(40.2 \%)$ & $<0.001$ \\
\hline $\begin{array}{c}\text { Intensive care } \\
\text { unit stay }\end{array}$ & $6(7.5 \%)$ & $48(20 \%)$ & 0.01 \\
\hline $\begin{array}{c}\text { Pneumonia } \\
\text { related } \\
\text { mortality }\end{array}$ & $5(6.3 \%)$ & $21(8.8 \%)$ & 0.478 \\
\hline
\end{tabular}

\section{Discussion}

The susceptibility to infections constitutes serious morbidity and mortality in diabetic patients. As blood glucose concentration increases, polymorphonuclear leukocyte function deteriorates. McMarus et al. showed that neutrophil function deterioration (decrease in phagocytic activity, decrease in chemotaxis, decrease in adherence, defect in exocytosis) was positively associated with hyperglycemia. There is also a decrease in intracellular oxidative activity. When lymphocyte subgroups are evaluated, the ratio of CD4 + T lymphocytes to CD8 + T lymphocytes (CD4 / CD8) can be found to be normal, increased or decreased.

In poorly controlled diabetes, disorders in cellular immunity occur in delayed type hypersensitivity reactions, lymphocyte transformation, and granuloma formation. These adverse changes in the immune mechanisms of patients with diabetes cause pulmonary infections to be common [6-12]. Van de Berghe et al. suggested that hyperglycemia causes cellular glucose overload and oxidative stress. They mentioned that this ultimately leads to organ and tissue dysfunction contributing to death [13]. In the study by Falguera M et al. [3] 606 patients with pneumonia were evaluated, 106 of them were diabetic. In this study, it has been reported that diabetes mellitus is associated with poor prognosis by increasing pleural effusion and mortality rate in patients with community-acquired pneumonia.

Kornum JB et al. [4] in their study, 34239 patients with pneumonia were evaluated and it was reported that diabetes mellitus was a risk factor for hospitalization related to pneumonia and poor long-term glycemic control increased the risk of hospitalization for pneumonia. In the study by Eurich DT et al. [5], it was reported that dysglycemia was not associated with mortality in hospitalized pneumonia cases. In our study, it was found that diabetic patients did not have a higher risk of pneumonia, but higher levels of HbA1c were significantly associated with intensive care unit stay. In our study, after the exclusion of patients with COPD, the statistical analysis revealed that need for intensive care unit follow up was lower in diabetics when compared to non-diabetic patients. In addition, diabetic patients had a similar mortality rate as non-diabetic patients.

\section{Conclusion}

The morbidity and mortality rate in diabetic patients with community-acquired pneumonia was not different from non-diabetic patients with community-acquired pneumonia. However, when diabetic patients with pneumonia were evaluated among themselves, the rate of morbidity and mortality was significantly higher for subjects with higher HbA1c levels. We believe that blood glucose regulation in diabetic patients will reduce the morbidity and mortality risk of pneumonia.

\section{References}

1. Shaw JE, Sicree RA, Zimmet PZ (2010) Global estimates of the prevalence of diabetes for 2010 and 2030. Diabetes Res Clin Pract. 87(1): 4-14.

2. Shah BR, Hux JE (2003) Quantifying the risk of infectious diseases for people with diabetes. Diabetes Care 26(2): 510-513.

3. Falguera M, Pifarre R, Martin A, Sheikh A, Moreno A (2005) Etiology and outcome of community-acquired pneumonia in patients with diabetes mellitus. Chest 128(5): 3233-3239. 
4. Kornum JB, Thomsen RW, Riis A, Lervang HH, Schønheyder HC, et al (2008) Diabetes, glycemic control, and risk of hospitalization with pneumonia: a population-based case-control study. Diabetes Care 31(8): 1541-1545.

5. Eurich DT, Gamble JM, Marrie TJ, Majumdar SR (2010) Dysglycaemia and 90 day and 1 year risks of death or readmission in patients hospitalised for community-acquired pneumonia. Diabetologia 53(3): 497 503

6. Debczyński W, Pietruska Z (1994) Chemotaxis and spontaneous migration of neutrophil leukocytes from patients with diabetes. Pol Tyg Lek 49(1-3): 11-13.

7. Marhoffer W, Stain M, Maeser E, Federlin K (1992) Impairment of polymorphonuclear leukocyte function and metabolic control of diabetes. Diabetes Care 15: 256-260.

8. Delamaire M, Maugendre D, Moreno M, Le Goff MC, Allannic H, et al (1997) Impaired leucocyte functions in diabetic patients. Diabet Med 14(1): 29-34.

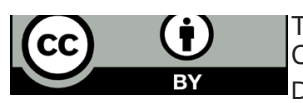

This work is licensed under Creative Commons Attribution 4.0 Licens DOI:_10.19080/JETR.2019.04.555634
9. Marfoffer W Stein M, Schleinkofer L, Federlin K (1994) Monitoring of polymorphonuclear leukocyte functions in diabetes mellitus..A comparative study of conventional radiometric function tests and low-light imaging systems. J Biolumin Chemilumin 9(3): 165-170.

10. McManus LM, Bloodworth RC, Prihoda TJ, Blodgett JL, Pinckard RN (2001) Agonist-dependent failure of neutrophil function in diabetes correlates with extent of hyperglycemia. J Leukoc Biol 70: 395-404.

11. Senior PA, Marshall SM, Thomas TH (1999) Dysregulation of PMN antigen expression in Type 2 diabetes may reflect a generalized defect of exocytosis: influence of hypertension and microalbuminuria. J Leukoc Biol 65(6): 800-807.

12. Alfonso C, Han JO, Williams GS, Karlsson L (2001) The impact of H2-DM on humoral immune responses. J Immunol 167(11): 6348-6355.

13. Aberegg SK (2006) Intensive insulin therapy in the medical ICU. N Engl J Med 354(19): 2069-2071.

\section{Your next submission with Juniper Publishers} will reach you the below assets

- Quality Editorial service

- Swift Peer Review

- Reprints availability

- E-prints Service

- Manuscript Podcast for convenient understanding

- Global attainment for your research

- Manuscript accessibility in different formats

( Pdf, E-pub, Full Text, Audio)

- Unceasing customer service

Track the below URL for one-step submission https://juniperpublishers.com/online-submission.php 